\title{
Editorial
}

\section{"ESCOLA DE ENFERMAGEM DA USP - JUBILEU DE OURO"}

A Escola de Enfermagem completará no próximo ano, cinqüenta anos de existência, numa trajetória permeada de grandes realizações e associada a grandes nomes do cenário brasileiro, tais como os Professores Benedito Montenegro, Enéas de Carvalho Aguiar, Edith de Magalhães Fraenkel, Wanda de Aguiar Horta, Odair Pedroso, Glete de Alcântara, Haidêe Guanais Dourado, Carlos da Silva Lacaz e Maria Rosa Sousa Pinheiro, que fizeram, a alguns ainda fazem, a história da saúde nas áreas da enfermagem e da mecidina.

A influência da nossa Escola, fez-se sentir, nestes quase cinqüenta anos, na maioria das Escolas de Enfermagem brasileiras por orientação direta ou indireta.

As instituições de assistência hospitalar consideradas de excelência em nivel nacional e internacional, como o Hospital Israelita Albert Einstein, Hospital Sírio Libanês, Hospital da Beneficência Portuguesa, Hospital 9 de Julho, além do nosso Hospital Universitário, entre outros, têm ou tiveram a sua estrutura e perfís assistenciais determinados e assegurados por docentes, mestres e doutorandos, da nosa Escola.

Instituições seculares como as Casas André Luiz, tem atualmente suas propostas de mudanças orientadas por docentes com a participação de alunos.

A Secretaria da Saúde do Município de São Paulo tem seus programas implementados com o suporte de um convênio onde o processo participativo tem suas raizes implantadas num departamento da nossa Escola.

Secretários da Saúde e Bem Estar de diversos municípios do Estado de São Paulo, tiveram seus perfís de enfermeiros comprometidos com a profissão, marcados nos bancos da nossa Escola.

A Associação Brasileira de Enfermagem, a Associação Brasileira de Educação em Enfermagem, o Conselho Federal de Enfermagem e os Conselhos Regionais, devem parte da sua constituição e sedimentação a docentes, ex-diretores e egnessos da Escola de Enfermagem da Universidade de São Paulo.

As revistas de maior expressão no cenário brasileiro e latinoamericano, como a Revista Brasileira de Enfermagem, a Revista da Escola 
de Enfermagem da USP, a Revista Enfermagem em Novas Dimensões e a Revista Paulista de Enfermagem, tiveram seus caminhos traçados e permeados por diretrizes e produção provenientes do corpo docente da EEUSP.

Países como o Uruguai, Argentina, Paraguai, Perú, México, Venezuela, Colômbia, Bolívia, Guatemala, Costa Rica, Equador, Chile, Nicarágua e Portugal, tiveram a oportunidade de utilizar a EE para o aprimoramento de algumas de suas enfermeiras.

Por outro lado, a EE tem tido seu mérito reconhecido de forma marcante em nivel internacional em diversas ocasiões: atualmente, uma professora foi convidada a assessorar e dirigir a implantação da primeira Escola de Enfermagem de Nível Superior para os países de língua portuguesa em Angola, onde já está há quatro anos, e que gerou uma articulação de intercâmbio de docentes brasileiras e alunos angolanos, na EE e na Escola de Enfermagem de Ribeirão Preto; outro exemplo é que pela primeira vez na história do Conselho Internacional de Enfermagem (ICN), sediado em Genebra, uma enfermeira brasileira, Professora Titular desta Casa, ocupa um lugar de destaque na administração deste Conselho, que congrega representações de cerca de 134 países.

Além destas incursões internacionais, um recente convênio assinado com a Universidade de Valência, que visa a complementação da formação de enfermeiros de nível universitário de forma a permitir o pleno exercício da profissão nos meios acadêmicos, e que provavelmente será expandido para a Comunidade Européia, caracteriza e determina, na nossa opinião, o perfil de competência desejável e esperado de uma Escola de Enfermagem da maior Universidade da América Latina.

As inúmeras iniciativas desta Universidade na área da saúde em âmbito interno, e as iniciativas originadas de cada uma das Unidades do Campus Pinheiros, junto aos serviços governamentais e não governamentais, associados aos respectivos perfís de competências predeterminados, pressupõem um novo direcionamento das atenções da Universidade na busca da redefinição do seu papel social na comunidade. Se, até agora, cada Unidade buscava implementar sua área de atuação na interface da relação escola-serviço, desenvolvendo competências específicas importantes para o futuro profissional, inovando, pesquisando e articulando recursos nos âmbitos dos seus interesses e necessidades emergentes, cabe, em futuro bem próximo, uma articulação interunidades, nos diversos campos do "saber e do fazer", que caracterizará a função social do cuidar e do tratar na saúde em seu sentido mais amplo.

A função social da Universidade transcende, o ensinar e pesquisar, contempla a formação de profisisonais aderentes a uma nova realidade mais concreta, gerando novas tecnologias e novos conhecimentos. A função social da Universidade não pode alijar-se do processo de articulação do saber e do fazer, seja por meio de compromissos de acompanhamento de seus egressos visando o seu desenvolvimento continuado e programado, seja por meio da orientação e acompanhamento dos serviços prestados à comunidade, no caso específico das profissões da área da saúde. 
Neste contexto, a articulação interna e externa das Unidades de Ensino na área da saúde da USP, ainda a ser implementada, é ponto prioritário para a reavaliação da situação dos profissionais e das cond:ções operacionais das instituições de assistência à saúde na comunidade.

A saúde é um direito inalienável do ser humano e um requisito para o seu bem-estar coletivo e para o desenvolvimento econômico e social de um país. São sobejamente conhecidas por todos nós, as condiçōes de acesso, de permanência, de assistência e de saida do sistema de saúde para a maioria da população brasileira.

Como ensinar nestas condições, buscando modelos alternativos de resolutividade teóricos ou parcialmente testados?

Há que se destacar neste cenário, um novo momento de inserção articulada das diversas formas do saber e do fazer na área da saúde, por parte da nossa Universidade, visando a qualidade dos serviços oferecidos à população, não só na assistência propriamente dita, mas principalmente, nos processos de educação para a promoção e manutenção da saúde da comunidade.

Finalizando, creio ser esta uma proposta avançada, própria de uma Unidade altamente comprometida com o seu papel social e consciente das suas competências, como também das suas limitações, mas determinada a não alijar-se do processo social de reconstrução do modelo de saúde vigente, não apenas em âmbito local e regional, mas também nacional.

Este é o caminho que nos propomos como um desafio para a segunda metade do sécuio, da nossa Escola de Enfermagem da USP.

Tamara Iwanow CIANCIARULLO

Diretora da Escola de Enfermagem da USP 